\title{
Moving East: how the transnational tobacco industry gained entry to the emerging markets of the former Soviet Union- part I: establishing cigarette imports
}

\author{
A B Gilmore, M McKee
}

Tobacco Control 2004;13:143-150. doi: 10.1136/tc.2003.005108

See end of article for authors' affiliations .

Correspondence to: Dr Anna B Gilmore, European Centre on Health of Societies in Transition, London School of Hygiene and Tropical Medicine, Keppel Street, London WCIE 7HT, UK; anna. gilmore@lshtm.ac.uk

Received 11 July 2003 Accepted 26 December 2004

\begin{abstract}
Objectives: To identify British American Tobacco's (BAT) reasons for targeting the former Soviet Union following its collapse in 1991 and the initial strategies BAT used to enter the region.

Design: Analysis of tobacco industry documents held at the Guildford BAT archive.

Results: Desire to expand to new markets was based in part on the decline in old markets. The large population, proximity to China, scope to expand sales to women and, in Central Asia, a young population with high growth rates made the former Soviet Union particularly attractive. High consumption rates and unfilled demand caused by previous shortages offered potential for rapid returns on investment. A series of steps were taken to penetrate the markets with the initial focus on establishing imports. The documents suggest that BAT encouraged the use of aid money and barter trade to fund imports and directed the smuggling of cigarettes which graduated from an opportunistic strategy to a highly organised operation. In establishing a market presence, promotion of BAT's brands and corporate image were paramount, and used synonymously to promote both the cigarettes and the company. The tobacco industry targeted young people and women. It used the allure of western products to promote its brands and brand stretching and corporate imagery to pre-empt future marketing restrictions.

Conclusions: BAT used the chaotic conditions in the immediate post-transition period in the former Soviet Union to exploit legislative loopholes and ensure illegal cigarette imports. Governments of countries targeted by the tobacco industry need to be aware of industry tactics and develop adequate tobacco control policies in order to prevent the exploitation of vulnerable populations. Marketing restrictions that focus on advertising without restricting the use of brand or company promotions will have a limited impact.
\end{abstract}

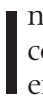
their 1848 Communist Party manifesto, Marx and Engels could have been forecasting the tobacco industry's rapid entry to new markets almost a century and a half later. They wrote that when domestic capitalism ceased to progress or experienced a crisis, industrialists would respond "by the conquest of new markets, and by the more thorough exploitation of the old ones". ${ }^{1}$ What they would not have predicted is the collapse of the Soviet Union in September 1991, the resulting upheaval, including widespread economic breakdown $^{2}$ and the stampede among the transnational tobacco companies (TTCs) to gain a share of these previously closed markets. $^{3}$

The 15 states emerging from the ruins inherited whichever parts of the Soviet tobacco industry lay in its territory but without the benefit of the centralised Soviet system of subsidies, inter-republic trade arrangements, and distribution mechanisms on which it had relied. Cigarette shortages that arose in the late 1980s worsened, leading to protests in major cities, in what became known as the tobacco rebellion. ${ }^{4}$ The stage was set for the entry of the TTCs who saw the former communist bloc-then the world's second largest cigarette market, with the Soviet Union alone the third largest market after China and the USA ${ }^{5}$ - as a golden opportunity. ${ }^{6}$ Patrick Sheehy, chairman of BAT Industries between 1982 and 1995, reflected their attitude when he stated in October 1990 that "[t]he dramatic increase in the proportion of the world's cigarette market now open to free enterprise [make these] the most exciting times I have seen in the tobacco industry in the last 40 years" $^{\prime 7}$

British American Tobacco (BAT), the world's second largest tobacco company, ${ }^{8}$ with the most extensive global presence, had in the 1980s expounded a policy of seeking new opportunities in markets hitherto the preserve of stateowned tobacco monopolies. ${ }^{7}$ The importance of the former Soviet Union (FSU) in this policy is perhaps best summed up by Tony Johnson, a BAT board member and regional lead for Russia and central Asia. In an in-house publication, the BAT Bulletin, he described the opportunities there as "almost limitless", explaining that:

"The emerging markets of Central Asia and the former Soviet Union in particular have immense potential and are of crucial significance to BAT. As the long established markets of north America and Europe mature and contract-and they will continue to do so over the next five to ten years - it is vital that we find new markets to grow and expand our business... the real opportunities for growth lie in the former Soviet Union and this is where we will be focusing much of our attention over the next few years." ${ }^{\prime \prime}$

Having recognised the opportunities available ${ }^{10}$ the "[a]ggressive exploitation of the emerging markets in Eastern Europe ${ }^{\prime \prime 11}$ became central to BAT's expansionist ideas and the need for "firm and aggressive strategies and plans to attack" specific markets was outlined. ${ }^{12}$

This paper, the first of two, is based on analysis of internal tobacco industry documents held at the BAT depository in

Abbreviations: BAT, British American Tobacco; CEE, Central and Eastern Europe; CIS, Commonwealth of Independent Sates; FSU, former Soviet Union; NIS, Newly Independent States; TTCs, transnational tobacco companies 
Guildford, UK. It explores the tobacco industry's interest in the markets of the FSU and its initial responses to their opening, focusing on the strategies adopted to increase imports (the second paper focuses on securing investments). Based largely on the TTCs previous entry to Asia and Latin America, it has been suggested that TTCs follow certain steps in developing a market presence, ${ }^{13-15}$ an initial focus on licensed production before joint ventures are established and national monopolies disbanded, and the use of smuggling as a market softening technique. However, little is yet known about the strategies and tactics used to enter the FSU. This knowledge is of particular importance for the few countries in the region where the industry remains state run, and those in other parts of the world still without TTC investment.

\section{METHODS}

A 1998 settlement between the tobacco industry and the state of Minnesota and Blue Cross Blue Shield of Minnesota led to the creation of two document depositories; one in Minnesota for the US cigarette companies and one in Guildford, UK for approximately eight million pages of BAT's internal records. Unlike the US companies, BAT was not required to make its documents available on the internet.

Searches were performed at the Guildford depository between July 2001 and February 2002. The index in Guildford is very crude, providing data at file rather than document level (each file contains an average of approximately 170 pages and a variable number of documents). An iterative approach was therefore taken to searching the archive. Initial searches used broad terms such as Soviet Union, FSU, NIS (Newly Independent States), CIS (Commonwealth of Independent Sates), Central Asia, plus the names of the 15 countries of the FSU. Thereafter names of key individuals, most notably BAT staff involved in the region, BAT projects, factories, cities, and so on were entered as search terms. In total 171 search terms were used to retrieve 1803 files (many of which were essentially duplicates). From these, over 600 documents were studied and indexed in detail in a specially designed database. This enabled sorting of documents by date and topic in order to construct a historical and thematic narrative. Secondary data were obtained from tobacco industry journals, newspaper reports and contacts in the field.

\section{RESULTS}

\section{Reasons for BAT's interest in the FSU}

BAT first became interested in the countries of Central and Eastern Europe (CEE) and the FSU in the late 1980s. With the assistance of the British Department of Trade and Industry and Treasury funded reports, they were able to track developments including legislative changes and the Russian privatisation process. ${ }^{16-18}$ A BAT study undertaken to explore the way in which Eastern Europe could be opened up for the company noted that:

\section{"If the changes in society and economy which have been announced are in fact implemented, the preconditions in these countries could be better than in many of the underdeveloped countries in the Third World."19}

The enormous size of the former Soviet market made it especially attractive-as INFOTAB (an industry-run international centre on smoking issues formed in 1979) noted in 1990, the population of Eastern Europe, estimated at 426 million (two thirds of which was in the Soviet Union) was considerably greater than that in each of the European Community, the USA, or Japan. ${ }^{20}$ BAT collated background data on the region which, inter alia, indicated very high rates of population growth and the young population structure of the central Asian republics. ${ }^{21}$ Market forecasts based in part on rates of population growth ${ }^{22}{ }^{23}$ suggested these features made these countries particularly attractive. In addition, BAT noted the potential to expand sales to women who, until then, had low smoking rates ${ }^{24}$ and, like all young people, were more likely to smoke international filter brands. ${ }^{24-27}$

Other reasons for BAT's interest were more specific to the region. The first was the shortage of cigarettes in the USSR. That demand far outstripped supply was noted first in Russia, ${ }^{28}$ then Ukraine, where between 1987 and 1991 the supply of filter cigarettes had halved from 30.8 to 15.8 billion, ${ }^{29}$ and later in central Asia. ${ }^{30}$ BAT assumed that consumption in these countries could be pushed back up towards its previous levels, even to levels found in Poland and Hungary, then among the highest in the world, as long as it was not allowed to stagnate at the low level that had resulted through supply shortages. ${ }^{12}{ }^{31}$ As Anton van Waay, (senior manager in BAT's new business development unit with an ambassadorial role in prospecting new markets), commented on the Ukrainian market:

\section{"The estimate of 80 bns [billions] market demand seems conservative if compared with consumption per capita in Hungary and Poland. If this market demand is not satisfied over a longer period, it should be questioned whether this theoretical demand will not disappear? ${ }^{\prime \prime 12}$}

Other factors that influenced BAT's interest were the potential for increasing leaf production in the region to supply its new investments ${ }^{32}$ and fulfil the company's aim of achieving growth through expanding leaf exports ${ }^{33}$ and, as we shall explore later, the FSU's proximity to China.

\section{Preliminary steps}

In 1989, BAT began to explore ways of entering markets within the Soviet bloc. ${ }^{34}$ It sought guidance from other western firms already successful in the Soviet Union, such as Rank Xerox, and was advised "not to prematurely jump into some grand joint venture" but to first "get "known" in the country". ${ }^{34}$ In light of this advice, and following visits to the region in 1988 and 1989, ${ }^{35}$ BAT developed a cautious, stepwise approach to penetrating the market ${ }^{34}$ (see website for details). Similar steps were outlined elsewhere ${ }^{19}$ and involved two main phases: the first to increase imports of BAT brands and the second to increase local production, initially via licensing and later joint venture..$^{19} 34$

Once the Soviet Union collapsed, plans remained similar.

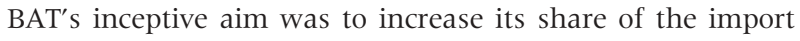
market and the overall scale of imports ${ }^{36}$ as this offered the best short term prospects ${ }^{37}$ and, as BAT had previously noted, could be achieved by "avoiding any significant investment on B.A.T's part" ${ }^{34}$ In the medium to long term BAT aimed to establish local manufacturing although the possibility of doing so independently, ${ }^{37}$ not just jointly with local interests, $^{34}$ was now recognised. In the early 1990s, however, BAT became concerned about the risks and costs of establishing a joint venture ${ }^{38}$ or greenfield operation ${ }^{39}$ at a time of great political uncertainty and that the imminent dissolution of the Union would limit access to the whole Soviet market. ${ }^{38}$ It therefore focused its efforts on obtaining a share of imports. ${ }^{40}$ These efforts form the focus of this paper.

\section{Establishing BATs brands in the market}

During the Soviet period, the supply of imported cigarettes was strictly controlled. BAT cigarettes had only formally been sold in airport duty free shops while BAT's competitors' (Philip Morris, RJ Reynolds, and Reemtsma) brands had 
been sold in the Beriozka (foreign currency) shops, whence "leakage" into the local markets secured brand visibility. ${ }^{34}$ These shops, established for tourists some 20 years previously, had, in BAT's words, become "the shop window for western lifestyle" and enabled cigarette companies to make their products known, their desirability fuelled by the fact that locals had little access. ${ }^{19}$

These efforts served to establish a degree of brand recognition among locals and an aspiration to obtain these elusive western products, a situation that BAT saw as a major opportunity. ${ }^{41}{ }^{42}$ BAT calculated that sales of western cigarettes would increase, not only by virtue of their better taste and quality, but because:

"...western cigarettes are seen as relatively inexpensive status symbols. Anyone who smokes foreign cigarettes distinguishes himself from the egalitarian doctrine of socialism and thus demonstrates more individuality or personal freedom on a small scale." 19

The priority therefore was to establish BAT's brands quickly to achieve a leadership position. ${ }^{36}{ }^{28}$ This was to be achieved in all new markets where BAT felt there was a "pent up demand for imported International Brands". ${ }^{36}$ Patrick Sheehy, chairman of BAT Industries, repeatedly stressed the need to register BAT's brands in as many countries as possible. ${ }^{43}$ He recommended that each company within the BAT Group review the issue monthly with their lawyers and continue "the practice of covering the use of brands on other, non-tobacco, products" ${ }^{43}$ In the FSU this was a complicated process. The concept of trademark ownership differed from the west-trademarks, where owned, were owned by the state not individual producers, with brands produced collectively across a number of factories. ${ }^{44}$ Moreover, closure of the Soviet Trade Mark office on I February 1992 made the means of registration outside Russia unclear. ${ }^{43}$

Simply placing brands on the market was insufficient; an effective distribution system had to be combined with brand marketing or what BAT referred to as its "pull" strategy:

\section{"To increase unit volume sales, BAT should combine its brand awareness effort ("pull" strategy) with limited investments in distribution and channel management strategies and opportunistic use of declining state distribu- tion assets ("push" strategy)" [original in caps]. ${ }^{45}$}

Brand marketing was required to build loyalty for brands that would ultimately be manufactured in the region. Thus establishing a brand strategy or portfolio was an immediate priority. ${ }^{46}$ Concerned at the potential advent of advertising restrictions, ${ }^{42}$ BAT, like the other TTCs, moved quickly to exploit the media opportunities available with massive advertising and sponsorship, ${ }^{47-50}$ unknown in the Soviet era. ${ }^{51-53}$

Although this paper does not intend to provide an overview of marketing practices, we note that certain consumers were seen as particularly important in establishing brand loyalty. Women were targeted through selected advertising ${ }^{27}$ and those living in urban areas through focused distribution systems. ${ }^{27}{ }^{45}$ But above all the emphasis appears to have been on younger, opinion leaders ${ }^{42} 46$ as one Russian marketing study suggests:

"Three factors are very clear:

(i) Most young Russians aspire to western international F.M.C.G [fast moving consumer goods] brands and will forego "necessities" in order to afford them.

(ii) Those that can afford to consistently buy western brands are younger consumers who are involved directly or indirectly in private enterprise and, ipso facto, are the "opinion leaders".

(iii) Consequently, advertising investment in brands now can establish a loyal core franchise on which to build a wider franchise as consumers' disposable income rises." ${ }^{42}$

Concern about advertising restrictions also led BAT to consider the role its corporate image could play:

"[a] good, high profile, corporate image will assist in opening up new markets, being seen as a good venture partner, and supporting our relationships with governments. If advertising restrictions make it difficult to introduce new brands, we may need to rely more heavily on the BAT name and its good corporate image." ${ }^{\prime \prime 36}$

The desire to establish a brand presence was also based on the need to enhance company visibility in order to promote BAT's position in joint venture negotiations. ${ }^{54}$ BAT felt that its lack of a globally recognised brand akin to Philip Morris' Marlboro or RJ Reynolds' Camel would be a disadvantage. For this reason it felt that "BAT should change company names to include BAT where there is an opportunity to do this, to improve visibility of the name ${ }^{\prime \prime} .55$

\section{Securing a place in the import market \\ Taking on the competition}

From the outset, BAT realised that time was of the essence stating "...Mikhail Gorbachev's amended statement: "If you come too late, history will punish you" also applies to us." ${ }^{\prime 19}$ Yet BAT was more cautious than its competitors in initial attempts to enter the market, most notably in establishing legal imports; in its own words, BAT "has not appeared to be as quick off the mark" [original emphasis]. ${ }^{55}$

In the rush to establish brands in the market, BAT's competitors were at an advantage as they had already completed several of the steps identified by BAT $^{34}$ - their cigarettes were already being sold in the foreign currency shops $^{34}$ and Philip Morris had established a licensing arrangement for Marlboro in the 1970s and developed trademarks with Soviet colleagues including the Apollo Soyuz cigarette to commemorate the space mission. ${ }^{5657}$

In 1990 BAT's major competitors again edged ahead-RJ Reynolds and Philip Morris concluded deals with the state importing agencies for Russia (Rosvneshtorg) and the Soviet Union (Prodintorg) ${ }^{38} 58$ for the import of 22-23 billion Philip Morris cigarettes and 19 billion Reynold's cigarettes ${ }^{38} 56$ to Russia and yearly supplies of 25 billion Philip Morris cigarettes thereafter. ${ }^{56}$ Media reports of the deal, ${ }^{59}$ including details that these companies airlifted 34 billion cigarettes to the region, ${ }^{4}$ suggest the contracts were honoured. Indeed, Philip Morris' 1990 deal was estimated to have added between US\$50-100 million to the company's operating profit through $1991^{59}$ despite BAT's assertion that low prices were paid..$^{38} 40$

BAT was keen to secure a similar deal ${ }^{4058}$ but its contacts with state organisations occurred too late for it to be included in these initial orders. ${ }^{38}$ Although later documents suggest it finally negotiated the official import of 12.5 billion cigarettes to Russia, ${ }^{43}$ its competitors' brands clearly had a head start. Thus by the time BAT was negotiating imports, other companies had begun to secure licensed production arrangements..$^{38} 40$

In exchange for import orders, the FSU countries wanted assistance in modernising their tobacco industries ${ }^{40}$ so national authorities were likely to give preferential treatment to imports from companies interested in investing. ${ }^{37}$ It appears that Philip Morris' success in securing import orders 
stemmed from its ability to convince governments of its longer term investment interest, even where none existed, by signing a letter of intent "well ahead of any serious commitment to an investment". ${ }^{37}$ BAT took a similar approach in preparing its strategy for securing import orders with state agencies. ${ }^{60}$

\section{Funding imports}

In the final years of the Soviet Union, the state had so little cash that it paid for the large orders placed with Philip Morris and RJ Reynolds partly by barter transactions: third parties in the west would buy wood, oil, and fertilisers from the Soviets and in turn make payments to the TTCs. ${ }^{38}$ Once the Soviet Union had collapsed, the economic position deteriorated further with a major economic crash in 1992. BAT recognised that there was no cash to pay for orders and that rapid price increases might lead to a decline in sales, ${ }^{55}$ yet remained so keen to establish imports that it was largely prepared to ignore these risks.

Instead BAT took advantage of its global reach to develop three main systems for ensuring the FSU countries could fund cigarette imports - counter-trade, smuggling, and the use of money from aid packages to fund cigarette imports. At one of the early meetings on market entry strategies attended by Patrick Sheehy (chairman of BAT), Martin Broughton (later chief executive and chairman of BAT), and Ulrich Herter (managing director tobacco, BAT Industries) it was noted that:

\section{"A key determinant of the ability to buy cigarettes will be the availability of hard currency either through aid packages or, in the case of the Russian trading organisa- tions, through exports of oil or other commodities sold in world markets. In addition, there could also be possibilities for counter-trade (e.g. Brazilian leaf for oil) ${ }^{\prime \prime 37}$}

At subsequent high level meetings further details emerged on how exports to Russia would be funded by aid packages. Minutes of a December 1991 meeting, for example, state: "[i]t was noted that Hollywood [a BAT brand] would be included in the offer for the EC [European Commission] financed project but would need to be manufactured in Europe, using a Souza Cruz blend of leaf imported from

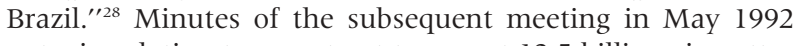
note, in relation to a contract to export 12.5 billion cigarettes to Russia via the state importing agency, that:

\section{"[ $t$ ]he major problem, which is being experienced by all importers, is arranging finance. Priority is being given to arranging payment from funds available from aid programmes, including a special sale of Jockey Club from Argentina, financed by funds from an Argentinean aid programme." 43}

International assistance programmes were also seen as offering less direct benefits such as funding to train local managers ${ }^{61}$ or improve leaf production. ${ }^{40}$

Although the documents suggest that European Union funds were used to pay for cigarette imports, we have been unable to verify this. The main source of European aid money to the region is the TACIS programme, a technical assistance programme established in 1991 to support the transition to democracy and market economy in Central and Eastern Europe and the FSU. In the first eight years of operating it committed a total of $€ 4226$ million of funding to projects. ${ }^{62}$ Although private sector development is a priority area for the programme, EC officials contract projects out to consultants and believe it would be difficult for money to have been misspent in this way (Personal correspondence Per Eklund, European Commission).

As in the late Soviet era, the use of barter transactions was another key strategy. Despite their shortfalls, BAT had used barter deals to import its HB brand into the Soviet Union noting that "it [barter] has to be utilized whenever possible and economically expedient in order to maintain or improve the brand awareness of our products". ${ }^{19}$ BAT learnt more about counter-trade from transnationals in other sectors, most notably Pepsi Cola International which had been running a franchise in the FSU for almost 14 years and had "wide experience of barter dealing as means of payment". ${ }^{63}$ To secure imports into Uzbekistan, for example, Murray Marr (BAT's project leader in central Asia) realised BAT would have to devise "creative means of securing payment which is ultimately convertible to hard currency"54 and on meeting with the chairman of Uzbakalea (the Uzbek state food distribution agency) to establish opportunities for "immediate importation" of BAT brands into Uzbekistan, agreed to produce a list of "acceptable barter goods" ${ }^{64}$

Ever optimistic, BAT even saw some benefits in the shortage of hard currency, noting that it could bring advantages as "[c]igarettes were and are always an important hard currency article in times of need." ${ }^{19}$ The same point was made by the Financial Times which noted:

"In Russia's hard pressed economy cigarettes are regarded not as a health hazard but as socially benign. Demand heavily outweighs supply, giving the status of a surrogate currency which, unlike the rouble, does not depreciate."

"Truck loads of Pall Mall, HB, Hollywood, Kent and Lucky Strike are now the currency in which many a domestic business deal is settled as well as a staple part of the retail trade."

Role of smuggling in new market access

Reports of the high level meetings on market entry referred to above show how, in their rush to establish imports, BAT planned "to pursue several channels in parallel" ${ }^{37}$ While some documents mention a number of import channels and operators, ${ }^{28} 384143$ the legality of which is difficult to establish, other documents suggest that smuggling was a key market entry strategy.

Previous work on BAT's role in smuggling indicates how BAT staff use euphemisms such as "general trade" and "transit" to refer to smuggling in their documents, while clarifying that transit "is essentially the illegal import of brands from Hong Kong, Singapore, Japan etc. upon which no duty has been paid." ${ }^{\prime 66-68}$ The BAT UK and Export Limited Company Plan 1993-1997 outlines how, in Central Europe, high import duties make the export environment unattractive but that "GT [General Trade] opportunities exist". ${ }^{69}$ BAT industries 1993 draft tobacco strategy document suggests that BAT was prepared to condone smuggling where excise policies were not favourable:

\footnotetext{
"We will seek to persuade governments to operate sensible excise and import policies, such that transit trade is reduced or eliminated, recognising that where there is an imbalance, market forces will operate.

Rationale: Transit trade is volatile and disruptive to the orderly operation of markets. It is in BAT's interest that markets are legal, taxed and controlled. However our primary responsibility is to meet consumers' demands as profitably as possible". ${ }^{36}$
} 
A regional marketing document confirms BAT's willingness to smuggle when excise rates are high, stating, "GT supplies of IBs [international brands] will continue to be the dominant supply source until duties are reduced to the range $30-50 \%$ (currently $98 \%$ in Russia) $)^{\prime 7}{ }^{70}$ BAT suggests that a gradual shift towards legal imports might occur in 1994, but its plan to "ensure that transition to fully paid duty scenario can be achieved without significant disruption to supply" implies that until that time, the majority of imports were smuggled..$^{70}$

A more detailed document exploring strategies for establishing brands in the FSU includes the following assumptions:

\section{- "GT will flourish" \\ - "GT Market will formalise in 1993 and continue through the plan" \\ - "Powerful International Brands will drive and benefit from the GT market" ; and \\ - "Establishment of brand image and consumer franchise are pre-requisites for success in GT." ${ }^{\prime \prime 1}$}

How a market supplied by contraband would "formalise" without direct industry involvement is unclear. The document goes on to outline individual brand strategies, including for State Express 555 the aim "[t]o generate sufficient franchise to benefit GT". BAT also notes its competitors' use of smuggled cigarettes stating "[h]igh volume competition brands will exploit $\mathrm{GT}^{\prime \prime}{ }^{41}$ and Philip Morris's strategic trademarks were "likely to remain mainly GT imports until duty change" ${ }^{\prime \prime}{ }^{70}$

A distribution study for Russia prepared for BAT by Bain Link (a management consulting firm) outlines the difficulties of operating in a chaotic and seemingly largely duty not paid market, $^{71}$ but once again suggests that BAT was operating largely within this illegal sector:

\section{"The [distribution] structure in place could serve as the skeleton for backward integration into [a] fully integrated distribution network when and if Russia becomes a duty- paid market. ${ }^{\prime \prime 71}$}

One of the disadvantages of developing a vertically integrated distribution system (in which BAT would develop its own distribution infrastructure) was that BAT could then be held responsible for tax compliance, something they were clearly keen to avoid. This document, for example, notes that vertical integration at the importer stage "would involve taking responsibility for tax compliance, resulting in a considerable competitive disadvantage in the current environment." ${ }^{\prime \prime 1}$ Similarly, by integration at the distribution stage "one level above and below the importer, there could be some implied responsibility for tax compliance."

The company's marketing strategy for the Russian Federation produced in $1994^{25}$ and related documents ${ }^{72}$ confirm how these issues play out in practice, stating:

\footnotetext{
"At the present time it is also not advisable for BAT to own or operate regional warehouses as this step would directly give us the burden of complying with customs regulations. Should the market become more oriented towards DPcigarettes [duty paid] we would have the chance of changing our distribution strategy based on our existing regional presence.

We should also be clearly aware of the fact that our opportunities for volume expansion are dependent on our importers to increase their volumes with special customs treatment. ${ }^{\prime \prime 25}$
}

Importantly, despite the apparent imperviousness of the borders of the Soviet Union, cigarette smuggling was not new. BAT's role in cigarette smuggling, including its major smuggling operation into China, has previously been documented. ${ }^{66} 6773$ Other documents highlight how, in the Soviet era, as part this Chinese operation, BAT supplied the SinoSoviet border trade with illegal cigarettes. This trade was already underway in $1986,{ }^{74}$ and involved considerable volumes. Monthly market reports from BAT (Hong Kong) Ltd for 1989 suggest that approximately 36-54 million cigarettes were supplied for this border trade each month ${ }^{75} 76$ with considerable increases predicted. ${ }^{76}$

While BAT's Hong Kong subsidiary was keen to promote this trade, uncontrolled "leakage" of these cigarettes from China was causing problems for BAT. ${ }^{77-79}$ This led Wai Pong, the general manager of BAT's Hong Kong subsidiary, to arrange for a consultant to report on the border trade. Visiting the "end buyer's office" the consultant reported that:

\section{"They [the Heilongiiang army] had signed a contract with Xiamen SEZ [Special Economic Zone] Trade Company Ltd and the latter had to supply 6000 cases of SE 555 [BAT brand State Express 555] to them per month. The Russian[s] liked SE 555 most but they also bartered other brands of cigarettes. The supply from Xiamen could not reach the contracted quantity in these two months and Xiamen claimed that the supply from BAT was not enough. ${ }^{\prime \prime 80}$}

Following a series of internal meetings on this illegal $\operatorname{trade}^{77} 78$ a decision was reached to reduce the supply of smuggled cigarettes to that area in an attempt to control the leakage:

\section{"...quantities supplied to Xiamen will be a factor of train loads, rather than a factor of container loads. We will do our best to ensure that nothing is left over for Mr Xie to either sell locally, or collect and sell elsewhere. ${ }^{\prime \prime 79}$}

However, instead of stopping the trade, more direct links were later established with the Chinese Army along the border. $^{74}$ as:

"...we have never doubted the existence of a demand on the Sino-Russian border. As a result of one important new circumstance, i.e. meeting and talking direct to the Army, we believe, and we hope we are right, that the business is genuine. In that belief it would be wrong to shut it out, or at least not try to and prove conclusively the validity of that belief." ${ }^{\prime \prime 9}$

Indeed, one of the major attractions of the FSU was its border with China, which after the opening up of the FSU remained the ultimate prize as the world's largest but officially closed cigarette market. Thus BAT's plans for the FSU included strategies for ensuring the illegal supply of cigarettes into China across this border. For example the 1994 "CIS [Commonwealth of Independent States] Operating Plan" outlined how BAT aimed to "[e]stablish supply [of the brand State Express 555] to cities on [the] Chinese border where personal transit opportunities exist".$^{70}$ A 1994 meeting exploring BAT's approach in central Asia implies that BAT intended to formalise this supply route when it notes that "[t]he strategy for this brand [State Express 555] will be reviewed when more is known about the GT [general trade] routes to China" ${ }^{81}$ The document goes on to outline how this 
specific issue would be examined in a study to be commissioned on distribution. ${ }^{81}$

\section{DISCUSSION}

The documents analysed in this paper provide insights into the strategic thinking behind the TTCs' focus on the FSU markets and highlight the elaborate and apparently devious and illegal tactics used to establish imports to the region. Although based on BAT documents, comments within these documents and our brief review of other company documents suggest that the attitude and practices of BAT's competitors were similar ${ }^{82} 83$ and included the use of smuggling. ${ }^{41} 5670$

\section{Marketing, brand, and corporate identity}

The documents suggest the FSU was a market ripe for exploitation, with the potential to provide immediate returns on investment. Favourable features included the undersupply of the market, ${ }^{28-30}$ the vast population ${ }^{21}$ and in some areas its young structure, ${ }^{21}$ high male smoking rates, and although few women smoked, ${ }^{24}{ }^{84-87}$ they, along with the young of both sexes, were more likely to smoke international filter brands. ${ }^{24} 27{ }^{42}$ As indicated in the documents, the TTCs set about exploiting these factors along with the status afforded to western products in general and cigarettes in particular ${ }^{19} 42$ by glamorising the western way of life ${ }^{88}$ and, as in its previous entry into Asia, ${ }^{15}$ making concerted efforts to appeal to women, young people, and opinion leaders. ${ }^{89}$

The levels of cigarette advertising that resulted were phenomenal. By the mid 1990s the industry reported that up to $50 \%$ of all billboards in Moscow and $50 \%$ of plastic bags in Russia carried tobacco advertising ${ }^{90}{ }^{91}$ and in at least four of the newly independent states the tobacco transnationals ranked among the top three advertisers. ${ }^{92}{ }^{93}$ Advertising practices have in turn been reflected in smoking prevalence patterns-recent surveys in the region show higher rates of smoking among women than previous surveys and far higher rates of smoking among younger than older women suggesting that female smoking is a relatively new phenomenon. ${ }^{86}{ }^{87}$ This targeting of women, few of whom previously smoked, refutes the common industry claim that advertising is only used to encourage brand switching.

In establishing imports, determining a brand strategy was clearly paramount. The documents highlight how the company's brands and corporate image were to be used synonymously to promote the company and market its products. ${ }^{3655} 54$ The collective focus on brands and corporate image was used to pre-empt the negative impact of potential advertising restrictions. In this regard it is of note that the chairman focused on the need for brand registration, in particular the requirement to register non-tobacco products, ${ }^{43}$ highlighting the important role of brand stretching. Collectively these documents highlight that corporate and product branding and marketing go hand in glove and show that marketing restrictions that focus solely on advertising without limiting the use of brand or company promotions will have a limited impact. Evidence from Brazil in which the response of BAT's subsidiary, Souza Cruz, to a comprehensive advertising ban was to use the company logo in promotions, illustrates this issue. ${ }^{94}$ Overall the contrast from the Soviet era when branding and advertising were unknown concepts to the post-Soviet era where branding and marketing were essential, co-dependent, and highly prevalent strategies could not have been greater.

\section{Smuggling}

Shepherd outlines how smuggling reaches its peak around the time that a TTC enters a market but was unable to implicate the TTCs directly in this process. ${ }^{13}$ These documents highlight clearly the role BAT played in smuggling.
Smuggling offers a number of advantages to TTCs. It acts as a market softening technique by creating demand for the (often highly desirable) smuggled product before a domestic manufacturing presence is established. This undermines local firms (which can then be more easily and cheaply acquired), makes it easier to argue the need for local manufacture on the basis that the demand for quality products led to the illegal supply and reduces government revenues. ${ }^{13}{ }^{14}$ Smuggling also ensures a ready supply of cheap cigarettes, thereby encouraging consumption by undermining public health efforts to moderate demand through price controls.

Having conquered the FSU and central and eastern Europe, the TTCs' major focus is the forbidden fruits of China. BAT's carefully organised smuggling arrangements highlight the importance it places on ensuring a brand presence in such closed markets. It is clear that Sino-Soviet cigarette smuggling was just a small part of BAT's major smuggling

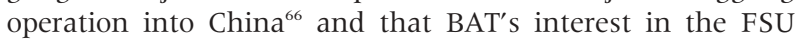
was predicated, at least in part, on the potential to manufacture cigarettes that could ultimately be supplied to the Chinese market.

In the FSU, the TTCs were undoubtedly aided in their smuggling efforts by the notoriously corrupt state customs committee $^{95}$ and its poorly paid officers. ${ }^{96}$ As expected, the widespread avoidance of import duties had a clear impact on government treasuries at a time of major economic hardship. ${ }^{97}$ Moreover, smuggling was not the only way that dutynot-paid cigarettes entered Russia. Legal systems for dutyfree cigarette imports were established under the auspices of the Russian Orthodox Church and the National Sports Fund ${ }^{98}{ }^{99}$ For the orthodox church, cigarettes were registered as humanitarian aid (along with any good given free) and the Church was allowed to import them duty free. ${ }^{100}$ This bizarre system apparently originated when a Dutch cigarette producer approached the Orthodox Church with a request to give the church its surplus production. Although we found no industry documents directly linking any of the TTCs to the Orthodox Church, other sources suggest Turmans, Rothmans' Dutch affiliate, gave 250000 packs of roll-yourown tobacco to the Soviet Union and could thus have initiated this deal. ${ }^{5}$ The Telegraph newspaper also reported that in the mid 1990s the Moscow Patriarchate entertained executives from Philip Morris. ${ }^{101}$

\section{Outcomes}

Although there were clear risks in importing cigarettes to a region in such economic disarray and BAT was relatively slow to act, later documents show that BAT's predictions of the potential of these markets was correct, noting that

\section{"[f]or several years now, the best new business develop- ment opportunities have been in the newly opened up markets in Russia, Eastern Europe and Central Asia and in the opening and fast developing markets of the Far East. ${ }^{\prime \prime 102}$}

This is perhaps more an indication that the conditions were ripe for industry expansion rather than a reflection of BAT's skill in harnessing the opportunities. The latent demand for cigarettes and desire for change after decades of Soviet rule, combined with newly established governments whose focus was by necessity on state-building and embryonic legislatures that lacked any tobacco control measures, meant that failure was almost impossible, especially when such high consumption rates had already been achieved without the benefit of marketing.

Although progress was not always straightforward, particularly in the Ukraine where trading conditions were difficult 


\section{What this paper adds}

Previous research in Asia and Latin America suggests the transnational tobacco companies take a staged approach to investing in new markets and use smuggling as a key market entry tactic. However, little is known about their entry to the former Soviet Union (FSU).

Based extensively on previously unseen documents from the Guildford archive, this is the first detailed analysis of market entry tactics in the countries of the FSU. The former communist markets were seen as providing opportunities at least as good as those in the developing world. British America Tobacco (BAT) aimed to stimulate demand so that consumption would reach the high levels seen in Poland and Hungary and to expand sales to new population groups, most notably women and young opinion leaders. As in other emerging markets the industry employed a staged approach to market penetration, involving imports and subsequent establishment of domestic production. A number of tactics including large scale involvement in smuggling were used to establish imports. BAT exploited the free availability of the media and planned for the advent of marketing restrictions by using brand stretching and corporate imagery from the outset to promote the company and its brands.

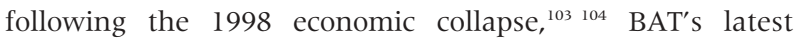
annual report indicates that the east European markets are generating good profits, with the five markets of Russia, Poland, Hungary, Romania, and Ukraine, where 10 years ago BAT had no production facilities, now accounting for $12 \%$ of group volume. ${ }^{8}$ Moreover, the report stresses that the group's success in eastern Europe has given BAT confidence in its ability to "grow share by entering new markets". These trends are reflected in industry-wide data for the eastern European region. Despite the difficulty of accurately estimating consumption because of the high rates of smuggling, since 1992 consumption in eastern Europe has grown steadily compared with a decline in western Europe. ${ }^{105}$ It is also the region with the greatest growth in market value-a $21.9 \%$ increase between 1995 and 1997. ${ }^{105}$

\section{Summary}

This is a story of greed and exploitation. Of course the TTCs were not the only ones exploiting the chaos that emerged from the FSU-the oligarchs, the mafia, and even the Orthodox Church also stood to gain. It is nevertheless clear that governments in markets that the TTCs seek to exploit need to protect themselves and their citizens from industry tactics. Most importantly they need to protect themselves from smuggling if they do not want to lose enormous revenues to the TTCs and encourage increased consumption of cheap cigarettes. They also need to ensure adequate legislation is in place to prevent unregulated tobacco promotions and thereby protect their populations from the devastating impact that entry of these companies can have on smoking patterns and hence the health of these vulnerable populations.

\section{ACKNOWLEDGEMENTS}

This work was supported by the National Cancer Institute, US National Institutes of Health, grant number R01 CA91021. The opinions are those of the authors alone.

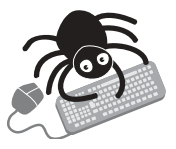

BAT's step wise approach to penetrating the market appears on the Tobacco Control website-http:// www.tobaccocontrol.com/supplement

\section{Authors' affiliations}

A B Gilmore, M McKee, European Centre on Health of Societies in Transition (ECOHOST), London School of Hygiene and Tropical Medicine, London, UK

\section{REFERENCES}

1 Marx K, Engels F. Communist manifesto. London: Lawrence and Wishard, 1983

2 Stiglitz J. Globalization and its discontents. London: Allen Lane, the Penguin Press, 2002.

3 Connolly GN. Tobacco, trade and Eastern Europe. In: Slama K, ed. Tobacco and health. New York: Plenum Press, 1995

4 Rupert J, Frankel G. In ex-Soviet markets, US brands took on role of capitalist liberator. Washington Post November 19, 1996.

5 European Bureau for Action on Smoking Prevention. Test the East. The tobacco industry and Eastern Europe. Brussels: BASP, 1991.

6 Action on Smoking and Health. Emerging markets. In: Tobacco explainedthe truth about the tobacco industry in its own words. London: ASH, 1998.

7 Campbell D. BAT Industries Plc in the 1980s and 1990s. In: Stonehouse G, Hamill J, Campbell D, Purdie T, eds. Global and transnational business: strategy and management. Chichester: Wiley, 2000.

8 British American Tobacco. Annual review and summary financial statement 2001. London: BAT, 2002. http://www. bat.com/AnnualReport2001/ annrev/13_download/Review.pdf last [Accessed 27 Feb 2003].

9 British American Tobacco. BAT Bulletin November 1994. Guildford Depository. BAT. Bates No. 500316187-8.

10 British American Tobacco. Slide material for DSW presentation 17.2.92: Royal Berkshire Hotel. 17/2/92. Guildford Depository. BAT. Bates No. 203471856-868.

11 British American Tobacco. BATCO Operating Group Five Year Plan 19931997. [1993]. Guildford Depository. BAT. Bates No. 203481292-365.

12 Van Waay A. Ukraine-Marketing. 23/04/1992. Guildford Depository. BAT. Bates No. 301689859-61.

13 Shepherd PL. Transnational corporations and the international cigarette industry. In: Newfarmer RS, ed. Profits, progress and poverty. Case studies of international industries in Latin America. Notre Dame, Indiana: University of Notre Dame Press, 1985.

14 Connolly G. Worldwide expansion of transnational tobacco industry. J Nt/ Cancer Inst Monographs 1992;12:29-35.

15 Mackay J. US Tobacco export to third world: third world war. J Ntl Cancer Inst Monographs 1992;12:25-8.

16 Department of Trade and Industry. Joint Ventures in Eastern Europe. August 1989. Guildford Depository. BAT. Bates No. 503078330-47.

17 KPMG Management Consulting. A study of the Russian Privatisation Process: Changing enterprise behaviour. BAT. 1993. Bates No. 203465968203466040.

18 Lowe, Roger. [Memo to BAT re KPMG study on Russian privatisation] BAT. 27 May 1993. Bates No. 203465967.

19 British American Tobacco. Study on Eastern Europe. 18/01/1990. Guildford Depository. BAT. Bates No. 203825453-92.

20 INFOTAB. Eastern Europe: Liffing the Curtain. October 1990. Guildford Depository. BAT. Bates No. 203825494-509.

21 Coplin WE, O'Leary MK, eds. East Europe \& the Republics. A political risk annual, 1 st ed. New York: Political Risk Services, 1992. Guildford Depository. BAT. Bates No. 201789689-704.

22 Marr M. Kyrgyzstan: Domestic market forecasts by segment. 30/08/1994. Guildford Depository. BAT. Bates No. 602750430-2.

23 Marr M. Uzbekistan. Preliminary marketing report following visit to Tashkent \& Samarkand 26-30 July. 11/08/1993. Guildford Depository. BAT. Bates No. 203832508-16.

24 Barnes M. Market research project-Executive summary-phase 2 (quantitative). Evaluation of Java, Cosmos and other domestic brands in Russia. 29/07/1993. Guildford Depository. BAT. Bates No. 50022884153.

25 Bielefeldt R. BAT marketing strategy for the Russian Federation. [1994]. Guildford Depository. BAT. Bates No. 500229227-41.

26 Moscow Sociological Agency. Special Group Discussions-Uzbekistan. Summary report. [06/09/1994]. Guildford Depository. BAT. Bates No. 203457726-39.

27 British American Tobacco. Russia Business outlook (facts and forecasts). [June 1994]. Guildford Depository. BAT. Bates No. 2034661 12-44.

28 British American Tobacco. New tobacco markets. 13/12/1991. Guildford Depository. BAT. Bates No. 203469386-94.

29 Van Waay A. Ukraine: Marketing strategy. 05/05/1992. Guildford Depository. BAT. Bates No. 301689856-8.

30 J Henry Schroder Wagg \& Co. Ltd. Preliminary review of the Transcaucasian and Central Asian Republics of the former Soviet Union. Volume I. August 1992. Guildford Depository. BAT. Bates No. 203456565-86.

31 British American Tobacco. Belarus: Note of a meeting held on 6 March 1995 at Windsor House. 20/03/1995. Guildford Depository. BAT. Bates No. 203477045-7.

32 British American Tobacco. Future leaf requirements of BAT operations in the CIS. Guildford Depository. BAT. Bates No. 602750626-8.

33 Barton H. NBD Strategy. 18/11/1992. Guildford Depository. BAT. Bates No. 201789654-8.

34 Haslam F. Note for TEC. Potential involvement with USSR. 20/02/1989. Guildford Depository. BAT. Bates No. 203827396-411.

35 Haslam F. Potential involvement with the USSR. 17/6/1991. Guildford Depository. BAT. Bates No. 203827394-5. 
36 Barton H. Draft BAT Industries Tobacco Strategy (Tobacco Strategy Group 19th May 1993, Agenda item 7. 12/05/1993. Guildford Depository. BAT. Bates No. 203469465-85.

37 British American Tobacco. Eastern Europe/USSR. 27/09/1991. Guildford Depository. BAT. Bates No. 201789795-7.

38 Tomat H. Visit to Moscow from 26th to 30th November 1990. Visit to Kiev from 10th to 11th December 1990. 20/12/1990. Guildford Depository. BAT. Bates No. 203827452-63.

39 Brookes N. Note to the CEC. Proposed BAT Tobacco investment strategy in Russia. [1993]. Guildford Depository. BAT. Bates No. 203466243-55.

40 Stevens B. Secret. Minutes of the meeting on Eastern Europe 9.00am on 23.1.91, Westminster House, London. 24/01/1991. Guildford Depository BAT. Bates No. 203827437-41.

41 Unknown. CIS Recommendation BATCo Brands. [1993]. Guildford Depository. BAT. Bates No. 500209752-95.

42 Marr M, Lewis L. Russia Marketing/distribution study Yava Factory, Nov. 23-Dec. 6 1992. 25/01/1993. Guildford Depository. BAT. Bates No. 500229032-98.

43 British American Tobacco. New Tobacco markets. 3/6/1992. Guildford Depository. BAT. Bates No. 203469395-403.

44 Van Waay A. Brand strategies E. Europe and former Soviet Union. Guildford Depository. BAT. 6 December 1991. Bates No. 203471338.

45 Bain \& Company, Inc. BAT Industries Russian distribution strategy final presentation. 21/09/1993. Guildford Depository. BAT. Bates No. 301755203-385.

46 Marr M. Moldova marketing plan 1994-2003. Discussion Draft. March 1994. Guildford Depository. BAT. Bates No. 602750435-51.

47 Direct Marketing Company Group. Press and TV Monitoring. Report on TV monitoring. Report for the month of January. [1993]. Guildford Depository BAT. Bates No. 500229012-27.

48 Phillips J. Club 555. 18/05/1994. Guildford Depository. BAT. Bates No. 500229110-7.

49 Titmuss V. CIS- Road to Wembley English FA Cup Sponsorship-555. 14/ 01/1993. Guildford Depository. BAT. Bates No. 500209748-9.

50 Zenith Media. Central and Eastern Europe market and mediafact. London: Zenith Optimedia, 2000.

51 Tomat H. Public Affairs in the CIS. 05/05/1993. Guildford Depository. BAT. Bates No. 502550121-2.

52 Zaridze D, Dvoirin VV, Kobljakov VA, et al. Smoking patterns in the USSR In: Zaridze DG, Peto R, eds. Tobacco: a major international health hazard. IARC Scientific publications NO. 74. Lyon: IARC, 1986.

53 Cooper R. Smoking in the Soviet Union. BMJ 1982;285:549-51.

54 Marr M. Uzbekistan-BAT Group brand presence. 04/02/1994. Guildford Depository. BAT. Bates No. 203459242-3

55 Barton H. New business development strategy. 11/05/1993. Guildford Depository. BAT. Bates No. 203469421-8.

56 Van Waay A. Secret. Note to Mr DS Watterton. Soviet Union. 19/02/1992 Guildford Depository. BAT. Bates No. 203471295-9.

57 Kholmogorova GT, Prokhorov AV. West goes East: the new tobacco situation in Russia. Tobacco Control 1994;3:145-7.

58 Tomat HA. Exports to Russia. 08/01/1991. Guildford Depository. BAT. Bates No. 203827435-6.

59 Zimmerman C. Update: Philip Morris. Pioneering the "New Europe". Tobacco Reporter February 1992. Guildford Depository. BAT. Bates No. 203827368-70.

60 Tomat H. Memo for discussion with Sir Patrick. Re: USSR. 15/01/1991. Guildford Depository. BAT. Bates No. 203827448-9.

61 van Waay A. Notes of meeting held at Windsor House, 11.2.92. EXA International, Paris. 12/02/1992. Guildford Depository. BAT. Bates No. 203827381

62 Anon. http://www.europa.eu.int/comm/europeaid/projects/tacis/ foreword_en.htm [last accessed 6 Mar 2003].

63 Rowlands-Rees G. Uzbekistan visit notes - 6th to 17th December 1993. 20/ 12/1993. Guildford Depository. BAT. Bates No. 203835038-41.

64 Marr M. Meeting Notes: MJM/Chairman Uzbakalea 22.2.94 Tashkent. 02/ 03/1994. Guildford Depository. BAT. Bates No. 203459229-30.

65 Rawstorne P. BAT poised to light up new market. 4/11/92. Guildford Depository. BAT. Bates No. 201789688.

66 The International Consortium of Investigative Journalists. Tobacco companies linked to criminal organisations in lucrative cigarette smuggling 2001, http://www.publici.org/story_01_030301_txt.htm [last accessed 13 Feb 2003]

67 Beelman MS, Campbell D, Ronderos MT, et al. Major tobacco multinational implicated in cigarette smuggling, tax evasion, documents show. International Consortium of Investigative Journalists, 2000. http:// www.publicintegrity.org/dtaweb/report.asp?ReportID = 80\&L1 = $30 \& \mathrm{~L} 2=10 \& \mathrm{~L} 3=10 \& \mathrm{~L} 4=0 \& \mathrm{~L} 5=0 \&$ Display $=\mathrm{ICI}$ [ [last accessed 31 Oct 2003].

68 Unknown author. "Re: Transit Study". Guildford depository. BAT 25th August 1989. Bates No.: 302000021-2.

69 BAT (UK and Export Limited). Company Plan 1993-1997. October 1992. Guildford Depository. BAT. Bates No. 502573663-719.

70 Unknown. BAT 1994 Media Meeting and CIS Operating Plan 1994. 07/ 12/1993. Guildford Depository. BAT. Bates No. 500209663-87.

71 Bain Link \& Co. Russian Distribution Strategy. [1993]. Guildford Depository. BAT. Bates No. 301755132-42.
72 Abery S. Re: 1995 plan. 30/06/1994. Guildford Depository. BAT. Bates No. 500229222-4

73 Beelman MS, Campbell D, Ronderos MT, et al. Global reach of tobacco company's involvement in cigarette smuggling exposed in company papers. International Consortium of Investigative Journalists, 2000. http:// www. publicintegrity.org/dtaweb/report.asp?Report $I D=$ $81 \& \mathrm{~L} 1=30 \& \mathrm{~L} 2=10 \& \mathrm{~L} 3=10 \& \mathrm{~L} 4=0 \& \mathrm{~L} 5=0 \& D i s p l a y=\mathrm{ICIJ}$ [last accessed 31 Oct 2003].

74 Aitken J. [Telex re Sino-Russian border supply]. 19/11/86. Guildford Depository. BAT. Bates No. 301634284.

75 Pong W. General Managers Monthly Review. January 1989 China. 2/2/ 1989. Guildford Depository. BAT. Bates No. 301634045-8.

76 Pong W. China. March 1989. Guildford Depository. BAT. Bates No. 301634036-8.

77 Coburn R. Hong Kong visit-27th August 1986. 27/8/86. Guildford Depository. BAT. Bates No. 301634332-3.

78 Coburn R. File Note; Hong Kong meeting-22nd September 1986. 25/9/ 86. Guildford Depository. BAT. Bates No. 301634322-4.

79 Aitken J. [Letter re Sino Russian border trade]. 28/10/86. Guildford Depository. BAT. Bates No. 301634282-3.

80 Cheung C. Heilongyiang Trip. [1/9/86]. Guildford Depository. BAT. Bates No. 301634326-8.

81 Aitken DJ. Minutes of BAT Central Asia/BATCo/BATCF/B\&W/NBD Meeting held in Tashkent 10th June 1994. 14/06/1994. Guildford Depository. BAT. Bates No. 203459365-74.

82 SIS International. RJR Nabisco Holdings Competitive Intelligence Profile Prepared for Phillip Morris (sic) USA. April 1993. Philip Morris. Access Date: 25 June 2002. Bates No. 2045122238-60. URL: http:// legacy. library.ucsf.edu/cgi/getdoc?tid = efg03e00\&fmt = pdf\&ref $=$ results.

83 RJ Reynolds. Former Soviet Union 1996 operating plan. [1995]. RJ Reynolds. [Access date 19 Nov 2003] Bates no.: 51 4870515-624. URL: http://legacy.library.ucsf.edu/tid/gtxO3a00.

84 Corrao MA, Guindon GE, Sharma N, et al. Tobacco control country profiles. Atlanta, Georgia: American Cancer Society, 2000.

85 McKee M, Bobak M, Rose R, et al. Patterns of smoking in Russia. Tobacco Control 1998;7:22-6.

86 Gilmore AB, McKee M, Telishevska R, et al. Epidemiology of smoking in Ukraine, 2000. Prev Med 2001;33:453-61.

87 Gilmore $\mathbf{A B}$, McKee $M$, Rose R. Prevalence and determinants of smoking in Belarus: a national household survey, 2000. Eur J Epidemiol 2001;17:245-53.

88 Hurt RD. Smoking in Russia: What do Stalin and western tobacco companies have in common? Mayo Clin Proc 1994;70:1007-11

89 Amos A, Haglund M. From social taboo to "torch of freedom": the marketing of cigarettes to women. Tobacco Control 2000;9:3-8.

90 Prokharov AV. Getting on Smokin' Route 66: tobacco promotion via Russian mass media. Tobacco Control 1997;6:145-6.

91 Dragounski D. Well-this is the Russian market. World Tobacco for Russia and Eastern Europe 1998;1I:32-46.

92 Anon. http://www.corporateinformation.com/vasector/Advertising.htm [last accessed 2 Jan 2001]

93 Anon. http://www.adageglobal.com/cgi-bin/pages.pl?link $=445$ [last accessed 5 April 2002]

94 Bialous SA. Advertising restrictions: getting them right can help business Alliance Bulletin Issue 36. Geneva: Framework Convention Alliance, 17 February 2003. http://www.fctc.org/newsletterlNB6.shtml [last accessed 15th April 2003].

95 Koriukin K. Cracking a new customs code. The Moscow Times 3 December 2001

96 Anon. Border bore. The Economist 15 December 2001

97 Arvedlund E. Tax collection under fire. St Petersburg Times, July 22-28 1996. http://www.sptimesrussia.com/secur/181-182/tax.html?725curr [last accessed 29 Nov 2001].

98 Korchagina V. Luzhkov appoints ex-sports fund boss. St Petersburg Times August 4-10 1997. http://www.sptimesrussia.com/secur/284-285/ luzhkov-appoints.html?725curr [last accessed 29 Nov 2001]

99 Taibbi M. Ousted chief of Sports Fund shot, stabbed. St Petersburg Times. June 23-30 1996. (http://www.sptimesrussia.com/secur/171-172/ ousted.html?725curr [last accessed 19 Nov 2001].

100 Gordeyev A. A blessed business. St Petersburg Times, November 18-24 1996. http://www.sptimesrussia.com/secur/213-214/bc.html?725curr [last accessed 29 Nov 2001].

101 Warren M. Criminals 'cashing in on Orthodox Church business empire'. The Telegraph, 30 June 2000. http://www.telegraph.co.uk/news/ main.jhtml?xml = \%2Fnews\%2F2000\%2F06\%2F30\%2Fworth30.xml [last accessed 3 July 2003].

102 Group Planning Department. BAT Industries - Future Business Environment 1996. Secret. 06/04/1995. Guildford Depository. BAT. Bates No. 500000489-526.

103 British American Tobacco. Quarterly report to 30 September 1998. London: British American Tobacco, 1998.

104 British American Tobacco. Quarterly report to 31 March 1999. London: British American Tobacco, 1999.

105 International Trade Publications Ltd. World tobacco file 1998-2001. London: DMG Business Media, 1998. 